\title{
Development of an Integrated Tool for Small-Scale Maize Farming in Uganda
}

\section{Louis J. M. Obura ${ }^{1,2}$, Robert K. Kambugu ${ }^{1 *}$, Nicholas Kiggundu${ }^{1}$, Hussein K. Balimunsi ${ }^{1}$, Samuel Kyamanywa ${ }^{3}$}

\author{
${ }^{1}$ Department of Agricultural and Biosystems Engineering, Makerere University, Kampala, Uganda \\ ${ }^{2}$ Department of Agricultural Engineering, University of Juba, Juba, South Sudan \\ ${ }^{3}$ Department of Agricultural Production, Makerere University, Kampala, Uganda \\ Email: oburalogy@gmail.com, ^kambugu@caes.mak.ac.ug, kiggundu@caes.mak.ac.ug, balimunsi@caes.mak.ac.ug, \\ skyamanywa@gmail.com
}

How to cite this paper: Obura, L.J.M., Kambugu, R.K., Kiggundu, N., Balimunsi, H.K. and Kyamanywa, S. (2020) Development of an Integrated Tool for Small-Scale Maize Farming in Uganda. Agricultural Sciences, 11, 653-666.

https://doi.org/10.4236/as.2020.117042

Received: June 22, 2020

Accepted: July 25, 2020

Published: July 28, 2020

Copyright $\odot 2020$ by author(s) and Scientific Research Publishing Inc. This work is licensed under the Creative Commons Attribution International License (CC BY 4.0)

http://creativecommons.org/licenses/by/4.0/

\begin{abstract}
About $62 \%$ of the maize produced in developing countries is cultivated manually owing to limited access to appropriate technology. Available technologies perform a single operation, necessitating farmers to buy multiple implements, which is expensive. In this study, an ox-drawn tool integrating a plough, planter and cultivator for small-scale maize farming was developed and its performance evaluated. Planting and cultivating units were designed and fabricated for assembly onto an existing standard ox-plough beam. The integrated tool was tested in the field to assess the effectiveness and efficiency of cultivation and planting of maize. Results showed that the planting unit had an average seed rate of $35.4 \mathrm{~kg} / \mathrm{ha}$ with a seed damage of $4 \%$ and an effective field capacity of $0.15 \mathrm{ha} / \mathrm{h}$ at a field efficiency of $87.3 \%$. The cultivating unit had an effective field capacity of $0.1 \mathrm{ha} / \mathrm{h}$ and a weeding efficiency of $86 \%$. The efficiency, effectiveness and reliability for field operations are superior to manual operations currently used by farmers and are comparable to single-unit prototypes developed in other countries. This demonstrates the technical feasibility of integrating planting and cultivation units onto an existing mould board plough instead of buying multiple tools.
\end{abstract}

\section{Keywords}

Integrated Tool, Plough, Cultivator, Mechanization, Smallholder Maize Farming

\section{Introduction}

Maize grain plays a critical role as a food and cash crop for over 32 million 
households in Sub-Saharan Africa [1]. However, according to [2], about 62\% maize produced in developing countries is cultivated manually. In Uganda, about $90 \%$ of the maize produced is cultivated manually on small-scale farms with limited access to appropriate technology [3]; these farms constitute close to $86 \%$ of the country's farming households [4]. Reference [5] projected that demand for maize will increase by $4 \%-8 \%$ per annum over the next two decades as a result of increased population. To meet this increasing demand, there must be an increase in production as well. However, most farmers continue to use manual tools resulting in low productivity [6] in addition to the associated drudgery. This has contributed to stagnation in maize production, raising concern over livelihood security for a considerable section of the population.

While there are several factors contributing to the problem of low production of maize in Uganda, heavy reliance on human muscles as the main source of farm power is a major impediment [7]. Agricultural production in Uganda is characterized by low levels of mechanization with only $10 \%$ of farmers using some form of mechanization [7] [8]. While the proportion of farmers in Uganda using Animal Draught Technology (ADT) is relatively higher (8\%) compared to use of engine power (2\%), its use is largely limited to ploughing operations [9]. The lack of appropriate technologies for mechanized farming operations in Uganda continues to be a major challenge to the goal of increasing agricultural production. Majority of farmers are low-income smallholders, unable to afford tractor-powered equipment while most of the available draught animal powered (DAP) equipments perform a single operation, making DAP and the associated tools relatively expensive as well.

Since modern agricultural equipment which is crucial to improved production is beyond the buying capacity of most smallholder farmers, there is need for low-cost equipment that can handle labor-intensive operations particularly ploughing, planting and weeding so as to increase maize production. A study conducted by [10] concluded that in areas where farmers use DAP equipment, significant improvements in production can be obtained through the introduction of small-scale farm implements and machines. Similarly, [11] argues that use of animal-drawn tools and equipment can increase yield of agricultural produce significantly and reduce labor demand in farming operations. In this paper, the process of developing and evaluating the performance of an integrated ox-drawn tool that combines a plough, planter and cultivator, for small-scale maize farmers in Uganda is described.

\section{Materials and Methods}

\subsection{Study Area}

The study was carried out from February to June 2017 at Makerere University Agricultural Research Institute, Kabanyolo (MUARIK) which is located at $0^{\circ} 20^{\prime} 23^{\prime \prime} \mathrm{N}, 32^{\circ} 36^{\prime} 10^{\prime \prime E}$ and about $21 \mathrm{~km}$ north of Kampala. According to [12], the study area has an average rainfall of $1100 \mathrm{~mm}$ with soil as classified as clay 
loam (36\% sand, $22 \%$ silt, $42 \%$ clay) with an average temperature of $21.5^{\circ} \mathrm{C}$.

\subsection{Design Concept}

The prototype was based on modification of a standard ox-plough beam (Figure 1) so that after detaching the bottoms it can serve as a multi-purpose toolbar able to accommodate the planting unit and cultivating unit components, attached separately depending on the farmer's need.

\subsection{Design of Cultivator Components}

The cultivating unit was designed for inter-row weed control in maize fields with an inter-row spacing of $75 \mathrm{~cm}$. The unit comprised of sweeps, shanks, cross beam and beam end attachment. These components were designed using standard procedures for design of machine elements. For soil-engaging components, duck-foot sweeps were selected due to availability on the local market and their ability to manipulate soil owing to their large wing width. Arrangement of sweeps (Figure 2) was chosen to achieve maximum weeding area between the rows without damaging the crop and was done in accordance with [13].

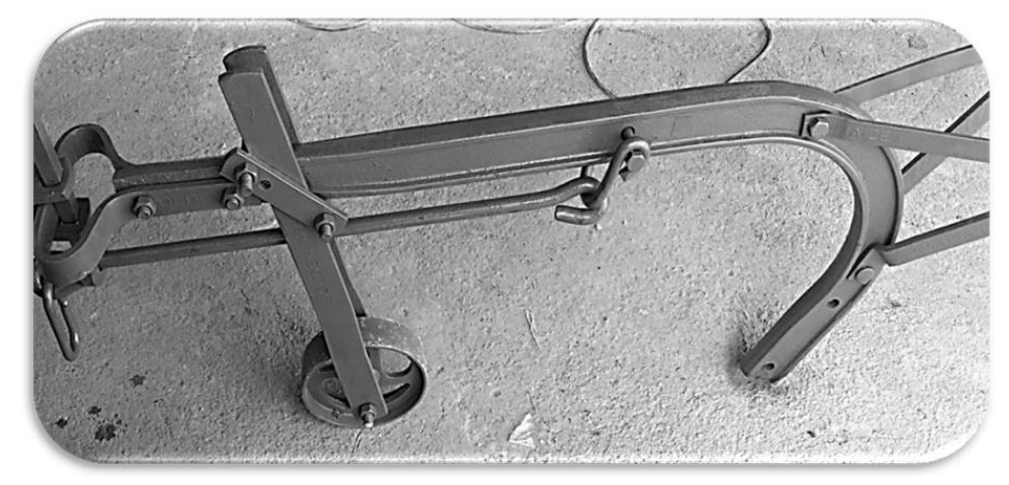

Figure 1. Standard ox-plough beam with bottom detached.

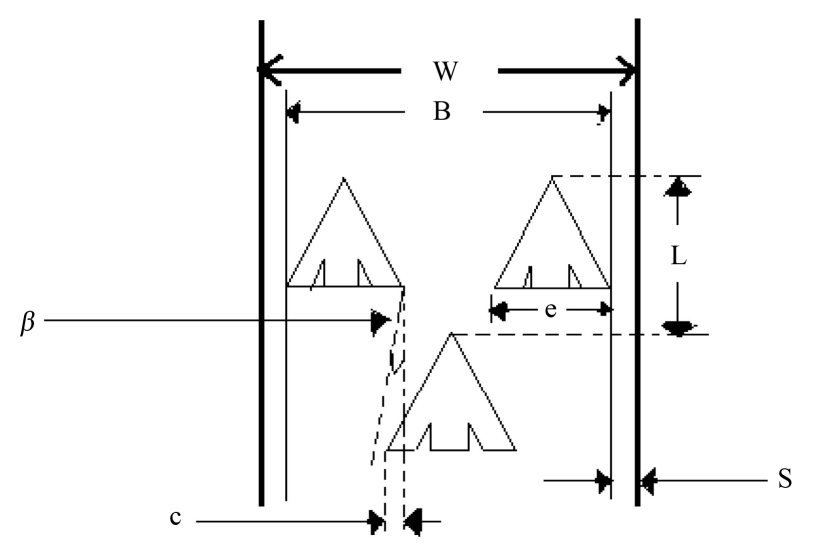

Figure 2. Sweeps arrangement for the cultivator, where, $B=$ cultivator working width (m), $W=$ inter-row maize spacing $(\mathrm{m}), S=$ distance between crop row and sweep edge (m), $N=$ number of the sweeps required, $c=$ sweep overlap $(\mathrm{m}), e=$ Sweep width, $\beta=$ Angle between the imaginary line linking the tail ends of two sweeps and the crop rows. 
Equations (1) and (2) were used for calculation of the cultivator working width and the number of sweeps required respectively.

$$
\begin{array}{r}
B=W-2 S \\
N=\frac{B-c}{e-c}
\end{array}
$$

Shanks were sized basing on the maximum bending moment they are subjected to in operation which was obtained by considering the shank as a cantilevered beam carrying a point load at the end with sweeps and fixed on the plough beam. The load on sweeps was obtained as the total draft force on soil-engaging components which is the product of sweep cross-section area and unit draft for clay loam soil in friable moisture condition. The cross beam, on which shanks are attached, was designed based on maize inter-row spacing (for its length) and the maximum shear force and bending moment (for cross-section dimensions) to ensure strength and rigidity.

\subsection{Design of Planter Components}

The planter was designed to sow two rows at ago and was comprised of drive wheels, a shaft for drive wheels, brackets for attachment of the shaft to the plough beam, a metering device, hopper, furrow opener, a seed discharge tube, a covering device and a frame for attachment of these components. The design of the drive wheel shaft involved selection of its diameter and material to withstand bending and torsion. The length of the shaft was based on maize inter-row plant spacing. The seed metering devices were made from wood as recommended by [10] due to its cost effectiveness and availability. To size the seed cells on the metering devices, dimensions of a random sample of maize seeds were measured using a Vernier caliper to determine their mean width, length and thickness. The diameter and depth of cells on the seed metering devices were determined on the basis of mean size of measured seeds with an allowance of $1 \mathrm{~mm}$ to facilitate movement of the seed into/out of the cells. The number of cells and distance between consecutive cells on the seed metering devices were obtained using Equations (3) and (4) [10] [14]:

$$
\begin{gathered}
m=\frac{\pi D_{w}}{I_{r s}} \\
t=\frac{\pi D_{s}}{m}
\end{gathered}
$$

where:

$$
\begin{aligned}
& m=\text { minimum number of cells on a roller, } \\
& D_{s}=\text { diameter of seed metering device }(\mathrm{m}), \\
& D_{W}=\text { diameter of planter drive wheel }(\mathrm{m}), \\
& I_{r s}=\text { intra-row spacing of seeds }(\mathrm{m}), \\
& t=\text { distance between consecutive cells }(\mathrm{m}) .
\end{aligned}
$$

The hopper was designed to feed the seed metering devices in the vertical di- 
rection to take advantage of gravity. The aspects considered in the design of the hopper were its volume, shape and material. The volume of the hopper was chosen such that it could accommodate $3 \mathrm{~kg}$ of maize seed while the shape was selected to ease seed delivery to the metering device by gravity. The volume of the hopper and its corresponding dimensions were determined from Equations (5) and (6).

$$
\begin{gathered}
V=\frac{m}{\rho} \\
V=\frac{B H-b h}{3}
\end{gathered}
$$

where:

$$
\begin{aligned}
& V=\text { volume of the hopper }\left(\mathrm{m}^{3}\right), \\
& m=\text { mass }(\mathrm{kg}), \\
& \rho=\text { bulk density }\left(\mathrm{kg} \cdot \mathrm{m}^{-3}\right), \\
& B=\text { base area of complete pyramid, }\left(\mathrm{m}^{2}\right), \\
& b=\text { base area of small pyramid cut out for frustum to form }\left(\mathrm{m}^{2}\right), \\
& H=\text { height of complete pyramid, }(\mathrm{m}) \text { and, } \\
& h=\text { height of the small pyramid }(\mathrm{m}) .
\end{aligned}
$$

The design of furrow openers was based on lower pull available and easy operation of the planter. Therefore, pointed furrow openers were chosen for improving seed placement and minimize seed rebounding. To achieve the depth of $50 \mathrm{~mm}$ for maize seed, a $30^{\circ}$ rake angle was chosen for the furrow openers [15]. The seed covering device was made from an iron angle bar attached to the frame with the help of a chain. It trailed the furrow opener to cover the seed. The design of the frame was based on the planter components to be mounted on it. Design factors considered in determining the materials required for the frame was strength to bear the weight of the components. A mild steel angle bar of $40 \mathrm{~mm}$ $\times 40 \mathrm{~mm} \times 3 \mathrm{~mm}$ was chosen. The frame was provided with holes where connections to the beam and other planter component's parts were attached. The discharge tube was made from mild steel hollow section $(20 \mathrm{~mm} \times 20 \mathrm{~mm})$ with a length of $140 \mathrm{~mm}$ and at a height of $50 \mathrm{~mm}$ from the ground to ensure proper placement of the seeds into the furrow.

\subsection{Testing of the Planting Unit}

The planting unit was calibrated in the workshop to assess rate of seed discharge and damage. The planter was lifted up the ground using concrete stands and the hoppers were loaded with $2.0 \mathrm{~kg}$ of maize seeds each. Cups were placed under each of the discharge tubes to collect the seeds metered and discharged. The drive wheels were rotated 30 times, a stop watch was used to measure the time taken to complete these revolutions and the wheel speed (rpm) was calculated. The seeds collected in cups were weighed; damaged seeds were separately weighed. The theoretical seed rate and percentage seed damage of the seed me- 
tering devices were calculated using Equations (7) and (8), respectively [10].

$$
\begin{gathered}
S_{r}=\frac{W_{m s} \times K}{W_{p} \times C_{d r} \times n} \\
M_{d}=\frac{W_{t d s}}{W_{m s}}
\end{gathered}
$$

where:

$$
\begin{aligned}
& S_{r}=\text { seed rate }(\mathrm{kg} / \mathrm{ha}), \\
& W_{m s}=\text { total weight of metered seeds }(\mathrm{g}), \\
& W_{p}=\text { width of the planter }(\mathrm{m}), \\
& C_{d r}=\text { circumference of the drive wheel }(\mathrm{m}), \\
& K=10 \text { is a units conversion factor, } \\
& n=\text { number of revolutions of the drive wheel, } \\
& M_{d}=\text { seed damage }(\%), \\
& W_{t d s}=\text { total weight of damaged seeds }(\mathrm{g}) .
\end{aligned}
$$

Field tests were carried out on an area of $15 \times 15 \mathrm{~m}$ that had been properly ploughed and harrowed. Maize seeds variety Longe 5 commonly grown in Uganda was obtained from an agricultural inputs supplier certified by MAAIF/NSCA were used to test and evaluate the planter. Longe 5 is an open-pollinated maize variety known for its drought tolerance and resistance to the grey leaf spot as well as maize streak virus diseases. It is recommended for altitudes ranging from 1000 $1600 \mathrm{~m} \mathrm{ASL}$ and matures in 110 - 120 days giving an average yield of $6 \mathrm{t} / \mathrm{ha}$. A random sample of kernels of Longe 5 used in this study had length in the range 11.5 - $14.5 \mathrm{~mm}$, width in the range $7.5-11.0 \mathrm{~mm}$, and thickness in the range 4.0 - $6.0 \mathrm{~mm}$. The planter was hitched to a pair of oxen, the furrow openers were adjusted to depth of $50 \mathrm{~mm}$ and furrow covering devices were lifted up to avoid covering the fallen seeds. Five runs of trial planting were conducted. Parameters measured during field tests included seed spacing and depth, planting time, turning time and length of operation.

Data collected were used to calculate the mean seed spacing, seed miss index $(S M I)$, seed multiple index $(D I)$, and miss index $(A)$ using Equations (9)-(11) following [14]. The theoretical spacing in this study was $30 \mathrm{~cm}$.

$$
\begin{gathered}
D I=\frac{n_{1}}{N} \times 100 \% \\
A=\frac{n_{2}}{N} \times 100 \% \\
S M I=\frac{n_{3}}{N} \times 100 \%
\end{gathered}
$$

where:

$n_{1}=$ number of seed spacing greater than half the theoretical spacing,

$n_{2}=$ number of seed spacing greater than half the theoretical spacing but less than or equal to 1.5 times the theoretical spacing, 
$n_{3}=$ number of seed spacing greater than 1.5 times the theoretical spacing,

$N=$ total number of seed spacing sampled.

The theoretical field capacity was calculated using Equation (12) [16].

$$
F C_{t}=\frac{S \times W}{10}
$$

where:

$F C_{t}=$ Theoretical field capacity, $(\mathrm{ha} / \mathrm{h})$.

$S=$ speed of travel in $(\mathrm{km} / \mathrm{h})$.

$W=$ theoretical width of operation of the machine $(\mathrm{m})$.

The effective field capacity was determined by measuring the effective area covered by the machine having measuring the width and the distance covered per run and the corresponding average. The effective field capacity was therefore evaluated from Equation (13) [16] [17] [18].

$$
F C_{a}=\frac{A}{10 T} \times 10000
$$

where:

$$
\begin{aligned}
& F C_{a}=\text { effective field capacity }(\mathrm{ha} / \mathrm{h}), \\
& A=\text { area covered by machine }\left(\mathrm{m}^{2}\right), \\
& T=\text { time taken by machine }(\mathrm{h}) .
\end{aligned}
$$

Field efficiency was obtained from Equation (14) as the ratio of actual field capacity to theoretical field capacity expressed in percentage.

$$
\text { Field efficiency }=\frac{F C_{a}}{F C_{t}} \times 100 \%
$$

\subsection{Testing of the Weeding Unit}

The cultivator was tested in average plot sizes of 80 by $10 \mathrm{~m}$ having maize planted at an inter-row spacing of $75 \mathrm{~cm}$ and an intra-row spacing of $30 \mathrm{~cm}$. The cultivator was adjusted to a working depth of $40 \mathrm{~mm}$ and hitched to the animals. During field tests, actual operating width and depth of cultivation were measured as well as the operation time and turning time. Two timers were used, one for time spent per each run along a row and the other one for total time taken to carry out the operation. The speed of operation was calculated from the time taken to weed a single row. This operation was replicated ten times and data collected was used for calculating the average field capacity and efficiencies. Weeding efficiency was calculated by counting weeds before and after weeding operation, measurements of weed cover, and total area of cultivation were measured. Crop damage was assessed by counting crop plant populations in each row before and after the passage of the cultivator. Data collected on the performance of the planting and weeding units were analyzed statistically using Minitab ${ }^{\circledR}$ 17.3.1 analytical statistical software package to get their mean maximum and minimum values with their standard errors (SE) and coefficients of variation $(\mathrm{CV})$. 


\section{Results and Discussion}

\subsection{Design Specifications for the Cultivation Unit}

Essential components for the cultivator unit include a depth adjustment wheel, two adjustable sweeps attached to the cross beam, one fixed sweep attached to the beam end and the handles (Figure 3 ). The specifications for these parts are presented in Table 1.

This cultivation unit is similar to the single-action toolbar designed by [13] except for the arrangement of the soil-engaging tools. The single-action toolbar had a weeding efficiency of $71 \%$ while the cultivator developed in this study achieved a $79 \%$ weeding efficiency.

\subsection{Design Specifications for the Planting Unit}

The planting unit is comprised of a frame on which other parts were assembled (Figure 4); the detailed specifications for the various parts are shown in Table 2. This planter is similar to a multi-crop planter developed by [10], the difference being the use of wood for the seed metering device in this prototype as opposed to aluminum.

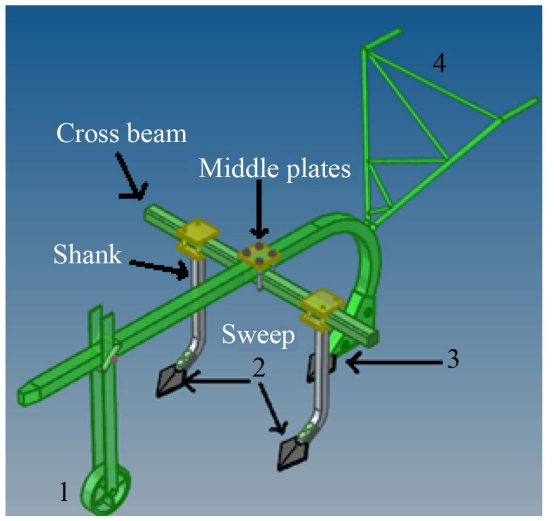

1-Depth adjustment wheel; 2-Front sweeps; 3-Hind attachment and sweep; 4-Handle sub-assembly

Figure 3. Cultivator components mounted on the plough beam.

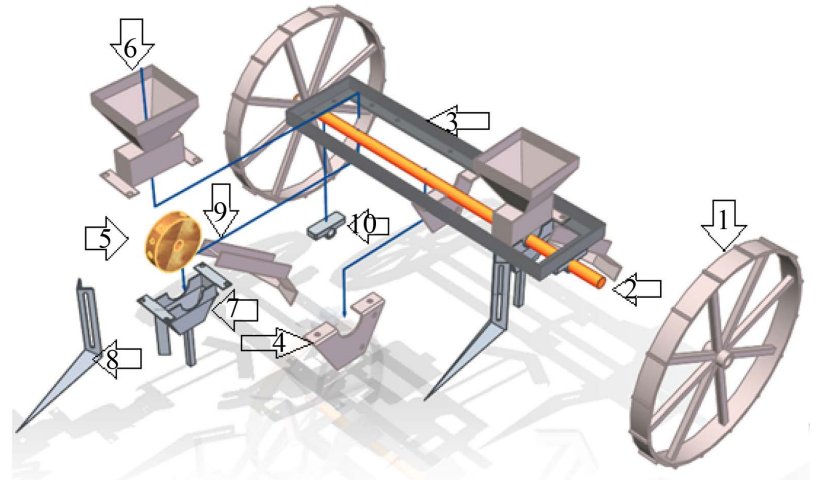

Figure 4. Exploded view of planting unit components. (Part details are given in Table 2). 
Table 1. Design specification for the major parts of the cultivator unit.

\begin{tabular}{cccc}
\hline Parts Name & Material & Dimensions $(\mathrm{mm})$ & Shape \\
\hline Cross beam & Mild steel & $900 \times 40 \times 3(L \times W \times t)$ & Square \\
Shank & Mild steel & $15 \times 15 \times 320(L \times W \times H)$ & Square solid \\
Sweep & High carbon steel & $270 \times 220 \times 60(L \times W \times H)$ & Duck foot \\
Middle plates & Mild steel & $150 \times 40(L \times t)$ & Square \\
\hline
\end{tabular}

Table 2. Description of the planting unit parts as shown in Figure 4.

\begin{tabular}{cccccc}
\hline $\begin{array}{c}\text { Part } \\
\text { No. }\end{array}$ & Parts Name & Material & Dimensions $(\mathrm{mm})$ & Shape & Qty. \\
\hline 1 & Drive wheel & Mild steel & $550 \times 50(\phi \times W)$ & Circular & 2 \\
2 & Drive shaft & Mild Steel & $30 \times 1100(\phi \times L)$ & Circular & 1 \\
3 & Main frame & Mild steel & $920 \times 240 \times 40(L \times W \times H)$ & Rectangular & 1 \\
4 & Frame-beam & Mild steel & $211 \times 100 \times 138.2$ & Inverted & 2 \\
& attachment & trapezoidal & \\
5 & Seed metering & Wood & $150 \times 40(\phi \times W)$ & Circular & 2 \\
& device & (Mahogany) & & Inverted & 2 \\
6 & Seed hopper & Mild steel & & truncated Pyramid & \\
7 & Seed metering & Mild steel & $160 \times 83 \times 64$ & Trapezoidal & 3 \\
8 & Furrow opener & Mild steel & & Shoe type & 2 \\
9 & Covering device & Mild steel & & V shape & 2 \\
10 & Pillow Bearing & Cast iron & & & \\
\hline
\end{tabular}

\subsection{Performance of the Planting Unit}

In terms of performance, the prototype developed in this study achieved mean field capacity, field efficiency and planting depth of $0.151 \mathrm{ha} / \mathrm{h}, 87 \%$ and 4.34 $\mathrm{cm}$, respectively. In comparison, corresponding figures for [10] were $0.12 \mathrm{ha} / \mathrm{h}$, $71 \%$ and $4.94 \mathrm{~cm}$, respectively. The planting depth achieved is within the acceptable range recommended for optimum germination of maize [19] and the recommended range for soil depth over seed in relation to seed size [20]. Since a uniform planting depth is necessary for better crop stands [21], the planting unit has the potential to help small-scale farmers to achieve better crop production. The mean effective field capacity of the planting unit was found to be $0.151 \mathrm{ha} / \mathrm{h}$ indicating that it takes a farmer slightly over six hours to plant a hectare of land which is more effective than planting with hoes and other ox-drawn planters.

One of the common problems associated with traditional methods of seed sowing is the high seed rate. The prototype was designed to address this challenge. Results obtained indicate that the average seed rate achieved by the developed planting unit ranged between $30 \mathrm{~kg} / \mathrm{ha}$ and $42 \mathrm{~kg} / \mathrm{ha}$ with an average of $35 \mathrm{~kg} / \mathrm{ha}$. The relatively higher seed rate may be attributed to the fact that the 
unit discharges 2 - 3 seed per seed cell. Available literature indicates that seeding rates for manually operated maize planters may vary considerably. For example, [6] reported a seed rate of $43.2 \mathrm{~kg} / \mathrm{ha}$ during their experiments on a manually operated maize seeding attachment for an animal drawn cultivator while [22] reported a seed rate of $35 \mathrm{~kg} / \mathrm{ha}$ from a study on modification and development of a two-row maize planter. These two studies show that the planter seed rate is within the range of what other researchers have achieved with two rows maize planters. [23] reported that seeding maize at below optimum rates increases risk of not attaining maximum yield potential for a given environment while seeding maize at populations above the optimal, increases risk of encountering stress at critical growth stages and suffering yield reductions.

Analysis of seed damage by the planter indicated that the percentage of damaged seed ranged between $3 \%$ and $5 \%$ with an average of $4 \%$, which is relatively high but comparable to results by other researchers including [24] and [25]. Analysis of differences in seed damage by the two seed metering devices using one-way ANOVA (Table 3$)$ showed statically significant differences $(\mathrm{p}<0.05)$ with the right hand seed metering device damaging more seed (5.2\%) than that on the left hand side (3.7\%). The relatively high seed damage may be attributed to flaws in the fabrication of the metering devices; for example, [26] attributed high percentage of damaged seeds to inadequate clearance in the seed metering device. According to [10], seed damage increased with increasing metering device speed and this was attributed to shearing and jumping of seeds against the wall of the hopper at high speeds and the magnitude of damage depended on the strength of the seeds. However, the effect of speed on seed damage was not investigated in this study.

In relation to seed spacing, the planter achieved an average seed spacing of 31 $\mathrm{cm}$, which is slightly higher than the design seed spacing of the planting unit which was set $30 \mathrm{~cm}$ as recommended for maize by agronomists. Additional tests done in relation to seed spacing were the average seed missing index (SMI), multiple index (DI) and quality of feed index. The results for those tests were as follows: $3 \%$ average seed missing index, $0 \%$ seed multiple index, $4 \%$ quality of feeding index which indicates that the planter has $97 \%$ precision in terms of seed spacing. This result is similar to [27], who found average field seed planting space by flute metering unit for maize as $34 \mathrm{~cm}$ compared to the theoretical value of $32 \mathrm{~cm}$. This result could be due to the seeds metering device housing and seed tube which are the major source of inaccuracy in seed spacing.

Table 3. One-way ANOVA for seed damage between left and right metering devices.

\begin{tabular}{cccccc}
\hline Source of variation & SS & DF & MS & F & p value \\
\hline Between devices & 69.000 & 1 & 60.900 & 65.154 & 0.000 \\
Within devices & 16.825 & 18 & 0.935 & & \\
Total & 77.725 & 19 & & & \\
\hline
\end{tabular}




\subsection{Performance of the Weeding Unit}

The cultivating unit was tested in the field at an average operating speed of 3.5 $\mathrm{km} / \mathrm{h}$. Results indicated that the cultivator mean working width was $43 \mathrm{~cm}$, the mean weeding depth was $3.5 \mathrm{~cm}$ while the cultivator mean weeding efficiency was $79.1 \%$. These results are comparable to those obtained by other researchers who did similar work but in different environments and contexts such as [28] [29] [30] [31]. The effective field capacity averaged $0.1 \mathrm{ha} / \mathrm{h}$ with minimum and maximum of $0.09 \mathrm{ha} / \mathrm{h}$ and $1.12 \mathrm{ha} / \mathrm{h}$, respectively. This indicates that it requires about 10 hours to weed one hectare of a maize field as opposed to 80 man-hours required when done manually as reported by [32] and [33]. Therefore, weeding using the developed cultivator can reduce time and labor requirements in farms. Reference [11] evaluated five-tined and three-tined animal drawn cultivators and found their effective field capacity to be $0.08 \mathrm{ha} / \mathrm{h}$ and $0.05 \mathrm{ha} / \mathrm{h}$, respectively. Hence this new developed cultivator is more efficient than both five- and three-tined cultivator developed by [11].

\section{Conclusions and Recommendations}

This study has demonstrated that it is technically feasible to integrate planting and cultivation units onto an existing mould board plough beam to develop an integrated tool suitable for use in small-scale maize farming. This approach to development of farm tools has potential to reduce ownership costs of equipment which may contribute their increased adoption. This would be in line with current strategies for agricultural transformation in Africa whereby mechanization has been identified among the critical inputs needed to reduce extreme drudgery while improving productivity and production. Results of performance testing for the prototype indicate that its level of efficiency, effectiveness and reliability for planting and weeding operations is superior to manual operations currently used by small-scale farmers in the county and is comparable to similar but single-unit prototypes developed in other parts of the world. This demonstrates that the prototype has potential to transform mechanization on smallholder farms which in turn can result in improved productivity and production on such farms. This would lead to improved food security and reduction in drudgery associated with hand tools thereby making agricultural work more decent.

It is recommended to make further improvement on the prototype prior to adoption especially perfecting the seed metering devices to reduce seed damage and to develop supplementary metering devices such that the planter can be used as a multi-crop planter to sow other crops like soy beans and groundnut. In addition, an economic and ergonomic evaluation for the new developed prototype needs to assess suitability. Further, more rigorous testing in farmers' fields with different soil types and conditions should be carried out to generalize field performance of the prototype.

\section{Acknowledgements}

The Norwegian Programme for Capacity Development in Higher Education and 
Research for Development (NORHED) under the project Regional Capacity Building for Sustainable Natural Resource Management and Agricultural Improvement under Climate Change (CAPSNAC) is acknowledged for the financial support towards the research project. CAPSNAC teams both at Makerere University and at University of Juba are also acknowledged for the administrative support and academic guidance.

\section{Conflicts of Interest}

The authors declare no conflicts of interest regarding the publication of this paper.

\section{References}

[1] Fisher, M. and Carr, E.R. (2015) The influence of Gendered Roles and Responsibilities on the Adoption of Technologies That Mitigate Drought Risk: The Case of Drought-Tolerant Maize Seed in Eastern Uganda. Global Environmental Change, 35, 82-92. https://doi.org/10.1016/j.gloenvcha.2015.08.009

[2] Koller, A.A., Rascon, J.A., Lam, E., Metcalf, M., Childers, A., Raun, B., Taylor, R. and Weckler, P. (2012) Design and Development of a Stick Planter for the Developing World. American Society of Agricultural and Biological Engineers Annual Meeting, Dallas, TX, 29 July-1 August 2012.

[3] UBOS (2016) The National Population and Housing Census 2014-Main Report. Uganda Bureau of Statistics Kampala, Kampala.

[4] UBOS (2010) Uganda Census of Agriculture 2008/2009, Volume IV: Crop Area and Production Report.

[5] Simiyu, S.W. (2014) Factors Influencing Maize Production among Small Scale Farmers in Kenya, a Case of Bungoma Central Sub County, in Department of Distance Studies. University of Nairobi, Nairobi.

[6] Olajide, O.G. and Manuwa, S.I. (2014) Design, Fabrication and Testing of a Low-Cost Row-Crop Planter for Peasant Farmers. Proceedings of the International Soil Tillage Research Organization (ISTRO) Nigeria Symposium, Akure, 3-6 November 2014, 94-100.

[7] Diao, X.; Silver, J. and Takeshima, H. (2016) Agricultural Mechanization and Agricultural Transformation. International Food Policy Research Institute, 1527.

[8] MAAF (2010) Agriculture Sector Development Strategy and Investment Plan: 2010/11-2014/15. International Food Policy Research Institute Kampala, Uganda.

[9] Wanyama, J., Banadda, N., Kiyimba, F., Okurut, S., Zziwa, A., Kabenge, I. and Kiggundu, N. (2016) Profiling Agricultural Engineering Technologies for Mechanizing Smallholder Agriculture in Uganda. Agricultural Engineering International: CIGR Journal, 18, 40-51.

[10] Tsegaye, A. (2015) Development of Animal Drawn Multi-Crop Planter. Ph.D. Doctoral Dissertation, Haramaya University, Haramaya.

[11] Ahmed, R. (2014) Performance Evaluation of Draught Animal Power Cultivator. Asian Journal of Applied Science Engineering, 3, 369-374. https://doi.org/10.15590/ajase/2014/v3i8/54949

[12] Deal, C., Brewer, C.E., Brown, R.C., Okure, M.A.E. and Amoding, A. (2012) Comparison of Kiln-Derived and Gasifier-Derived Biochars as Soil Amendments in the 
Humid Tropics. Biomass Bioenergy, 37, 161-168. https://doi.org/10.1016/j.biombioe.2011.12.017

[13] Sims, B.G. (2000) Elements of Design and Evaluation of Animal-Drawn Weeders. In: Starkey, P. and Simalenga, T., Eds., Animal Power for Weed Control, a Resource Book of the Animal Traction Network for Easter and Southern Africa (ATNESA), Technical Centre for Agricultural and Rural Cooperation (CTA), Wageningen, the Netherlands, 94-104.

[14] Khan, K., Moses, S.C. and Kumar, A. (2015) The Design and Fabrication of a Manually Operated Single Row Multi-Crops Planter. IOSR Journal of Agriculture Veterinary Science, 8, 147-158.

[15] Choudhari, D. (2001) Performance Evaluation of Various Types of Furrow Openers on Seed Drills. Journal of Agricultural Engineering Research, 79, 125-137.

[16] Singh, J. and Yadaw, M. (2014). Testing and Evaluation of Animal Drawn Multi-Purpose Tool Seed cum Fertilizer Drill. International Journal of Scientific Engineering Technology, 3, 463-466.

[17] Oduma, O., Ede, J.C. and Igwe, J.E. (2014) Development and Performance Evaluation of a Manually Operated Cowpea Precision Planter. International Journal of Engineering Technology, 4, 693-699.

[18] Hanna, M. (2001) Estimating Field Capacity of Farm Machines. PM 696. Extension and Outreach, Ames, Iowa, 1-4.

[19] Belfield, S. and Brown, C. (2009) A Guide to Upland Cropping in Cambodia: Maize. Australian Government. Australian Centre for International Agricultural Research, Canberra.

[20] Woo, S.M., Uyeh, D.D., Sagong, M.S. and Ha, Y.S. (2017). Development of Seeder for Mixed Planting of Corn and Soybeans. International Journal of Agricultural Biological Engineering, 10, 95-101.

[21] Madanzi, T., Chiduza, C. and Richardson-Kageler. (2010) Effects of Planting Method and Seed Size on Stand Establishment of Soybean [Glycine max (L.) Merrill cV. Solitaire]. Soil Tillage Research, 106, 171-176. https://doi.org/10.1016/j.still.2009.12.003

[22] Rabbani, M.A., Hossain, M.M., Asha, J.F. and Khan, N.A. (2016) Design and Development of a Low Cost Planter for Maize Establishment. Journal of Science, Technology Environment Informatics, 4, 270-279. https://doi.org/10.18801/jstei.040116.30

[23] Aikins, S.H.M., Bart-Plange, A. and Opoku-Baffour, S. (2010) Performance Evaluation of Jab Planters for Maize Planting and Inorganic Fertilizer Application. Journal of Agricultural and Biological Science, 5, 29-33.

[24] Alhassan, E.A., Adewumi, A.D. and Okpodjah, B. (2018) Development of a Self-Propelled Multi-Crop Two Rows Precision Planter: A New Design Concept for the Metering Mechanism. International Journal of Mechanical Engineering Technology, 9, 349-358.

[25] Osadare, T. and Manuwa, S.I. (2019) Performance Evaluation of A Pulse Planter Developed for Conservation Agriculture. Journal of Agriculture and Veterinary Science, 12, 15-21.

[26] Bautista, E.G., Gagelonia, E.C., Abon, J.E., Corales, A.M., Bueno, C.S., Banayo, N.P.M.C., Lugto, R.V., Suralta, R.R. and Kato, Y. (2019) Development of Hand Tractor-Mounted Seed Drill for Rice-Based Cropping Systems in the Philippines. Plant Production Science, 22, 54-57. 
https://doi.org/10.1080/1343943X.2018.1562309

[27] Adisa, A.F. (2011) Design and Construction of Manually Operated Flute Planter with Fertilizer Distributor. Science, 10, 178-183.

[28] Devojee, B., Meena, S.S., Sharma, A.K. and Agarwal, C. (2019) Performance Evaluation of Weeder by Number of Blades per Flange in Maize Crop. International Journal of Current Microbiology and Applied Sciences, 8, 2389-2397.

https://doi.org/10.20546/ijcmas.2019.804.278

[29] Kumar, S., Kumar, A. and Kumar, S. (2017) Performance Evaluation of Developed Manually Operated Rotary Weeder for Vegetable Crops. International Journal of Current Microbiology and Applied Sciences, 6, 4012-4019.

https://doi.org/10.20546/ijcmas.2017.611.470

[30] Sahu, M. Goel, A.K. (2017) Development of a Multipurpose Power Weeder. Power, 58, 3527-3531.

[31] Bhavin, R., Khardiwar, M.S., Kumar, S. Solanki, B.P. (2016) Performance Evaluation of Manual Operated Single Row Weeder for Groundnut Crop. International Journal of Agricultural Science and Research (IJASR), 6, 201-210.

https://doi.org/10.15740/HAS/ETI/7.1/45-52

[32] Ajewole, P.O. and Elegbeleye, K.E. (2011) Development of a Speed Selection System for a Mechanical Weeder. Proceedings of the 7 th Engineering Forum, Ado Ekiti, Nigeria, 154-157.

[33] Quadri, A.W. (2010) Design, Construction and Testing of Manually Operated Weeder. BSc. Thesis, Department of Agricultural Engineering, University of Agriculture Abeokuta, Ogun State, Nigeria. 